\title{
Best Practice Program Corporate Social Responsibility (CSR) PT. Pertamina RU II Production Sungai Pakning
}

\author{
Dadang Mashur \\ Public Administration, Universitas Riau
}

\begin{abstract}
The Commitment of one of the state companies PT. Pertamina in implementing Social and Environmental Responsibility (TJSL) is realized in various CSR activities covering the fields of education, health, environment, infrastructure, community empowerment, disaster management, and special assistance. The realization of activities is carried out by all working units of Pertamina's CSR functions, both at the head office, unit operations, and subsidiaries such as the Sungai Pakning Refinery Unit (RU) II Production. Pertamina implements CSR programs for people, planet and profit (3P) purposes. This goal is the focus of Pertamina in running its operations, where products are developed and services provided care about environmental sustainability, especially the earth for the interests and future of future generations. Pertamina's CSR focuses on four issues that become its pillars, namely: Pertamina Cerdas, Pertamina Sehati, Pertamina Hijau, and Pertamina Berdikari. This article is the result of research conducted with qualitative methods with a participatory approach.
\end{abstract}

\section{Keywords: \\ Best Practice, CSR, Empowerment}

\section{Introduction}

The policy of the Government of the Unitary State of the Republic of Indonesia which issued Law Number 40 of 2007 concerning Limited Liability Companies, which in article 74 contains provisions concerning "the company carrying out its business activities in the fields and / or relating to natural resources to carry out Social and Environmental Responsibility" Then the government issued Government Regulation Number 47 of 2012 dated April 4, 2012 concerning Social and Environmental Responsibility of Limited Liability Companies as the implementing regulation, then the United Nations Environment Program (UNEP) in 2008 declared the Green Economy movement to implement the concept Real sustainable development.

On November 1, 2012, the ISO 26000 International Guidance on Social Responsibility was officially released which provides an official formulation of the definition of Social responsibility as: corporate responsibility for: the impact caused as a 
result of its decisions and activities in society, and the environment, through ethical behavior and transparent that contribute to sustainable development; including public health and welfare; pay attention to stakeholder expectations; comply with applicable laws and regulations and are consistent with the norms of international behavior; and integrated in the organization and implemented in all organizational activities related to corporate organizations. In response to the policy, PT. Pertamina, as one of the state-owned companies in Indonesia, which runs its business in relation to natural resources, contributes to implementing the policy through the Corporate Social Responsibility (CSR) program.

Pertamina manages CSR programs including the Community Development (BL) program and the Partnership Program (PK). The strategic objective of Pertamina's CSR program is to improve Pertamina's reputation and credibility through CSR activities that are integrated with business strategies. To realize this goal, Pertamina implements major strategies, such as:

1. Mutual benefit (fair shared value)

2. Sustainability

3. Priority of operating area and affected area

4. Development of green energy as a responsibility for the impact of operations

5. Effective dissemination and publication

Pertamina's commitment in implementing Social and Environmental Responsibility (TJSL) is manifested in various CSR activities that cover the fields of education, health, environment, infrastructure, community empowerment, disaster management, and special assistance. The realization of the activities was carried out by all Pertamina's CSR work units, both at the head office, operating units, and subsidiaries such as the Sungai Pakning Production Refinery Unit (RU) II. Some activities, especially in the field of education, are carried out together with Pertamina Foundation. Under the umbrella of the theme "Pertamina Sobat Bumi", Pertamina implements CSR programs for the purpose of people, planet and profit (3P). This goal is the focus of Pertamina in carrying out its operations, where the products developed and services provided care about environmental sustainability, especially the earth for the benefit and future of future generations. Pertamina's CSR focuses on four issues which become its pillars, such as: 
1. Smart Pertamina

2. Pertamina Sehati

3. Green Pertamina

4. Pertamina is independent

In 2016, PT. Pertamina RU II Production of Sungai Pakning focuses on the implementation of CSR to support the achievement of PROPER by prioritizing environmental aspects, both nature and society in accordance with the requirements set by the PROPER Board (Ministry of Environment and Forestry of Indonesia). As a result, PT. Pertamina RU II Production Pakning River won 2 gold candidates in 2016 and 2017. Then PT. Pertamina RU II Production of Sungai Pakning also won UNS SME, s AWARDS category of Zero Waste MSME developer in 2017 and 2018. Furthermore, it won the Best of the Best Emerald CSR at the 2018 Nusantara CSR Award.

The flagship CSR program of PT. Pertamina RU II Pakning River Production in achieving these achievements are: Berdikari Peat Village, Gold Generation and Green Gems. These three excellent programs aim to solve the problems that occur in the area of PT. Pertamina RU II Production Pakning River which can be seen in the table below:

Table 1.

Identification of problems in the PT. Pertamina RU II Production Pakning River

\begin{tabular}{|c|c|c|c|c|}
\hline No & Problem & Program & Activity & Purpose \\
\hline 1 & $\begin{array}{l}\text { The rate of abrasion reaches } 5 \\
\text { meters / year, so that } \\
\text { residential areas have shifted } \\
100 \text { meters ashore to avoid } \\
\text { abrasion } \\
\text { Exploitation of mangrove } \\
\text { wood, so that } 15.66 \text { hectares of } \\
\text { mangrove land in the village } \\
\text { of Pangkalan Jambi deerk } \\
\text { Low fish catches, sea catches } \\
\text { have drastically decreased due } \\
\text { to damage to mangrove } \\
\text { ecosystems and local fish } \\
\text { catches have not been } \\
\text { optimally processed }\end{array}$ & $\begin{array}{l}\text { Green Gems } \\
\text { (Preservation } \\
\text { of applied } \\
\text { mangroves } \\
\text { and utilization } \\
\text { of mangrove } \\
\text { ecosystems } \\
\text { through } \\
\text { environmental } \\
\text { ly friendly } \\
\text { technologicall } \\
\text { y friendly } \\
\text { tilapia } \\
\text { aquaculture) }\end{array}$ & $\begin{array}{l}\text { Revitalization } \\
\text { and } \\
\text { Conservation } \\
\text { of Mangrove } \\
\text { Areas with } \\
\text { Hybrid } \\
\text { Engineering } \\
\text { Technology } \\
\text { Mangrove } \\
\text { Education } \\
\text { Center } \\
\text { Pangkalan } \\
\text { Jambi } \\
\text { Brackish Water } \\
\text { Tilapia Fish } \\
\text { Cultivation }\end{array}$ & $\begin{array}{l}\text { Coastal } \\
\text { Community } \\
\text { Empowermen } \\
\mathrm{t}\end{array}$ \\
\hline 2 & $\begin{array}{l}\text { The condition of school } \\
\text { infrastructure in Kec. Bukit } \\
\text { Batu is bad } \\
2,155 \text { school-age children are } \\
\text { disrupted by forest and land }\end{array}$ & $\begin{array}{l}\text { Gold } \\
\text { Generation } \\
\text { (Creating a } \\
\text { smart, } \\
\text { independent }\end{array}$ & $\begin{array}{l}\text { Cadres based } \\
\text { Posyandu } \\
\text { Sehati }\end{array}$ & $\begin{array}{l}\text { Improving the } \\
\text { quality of } \\
\text { health for } \\
\text { toddlers and } \\
\text { pregnant }\end{array}$ \\
\hline
\end{tabular}




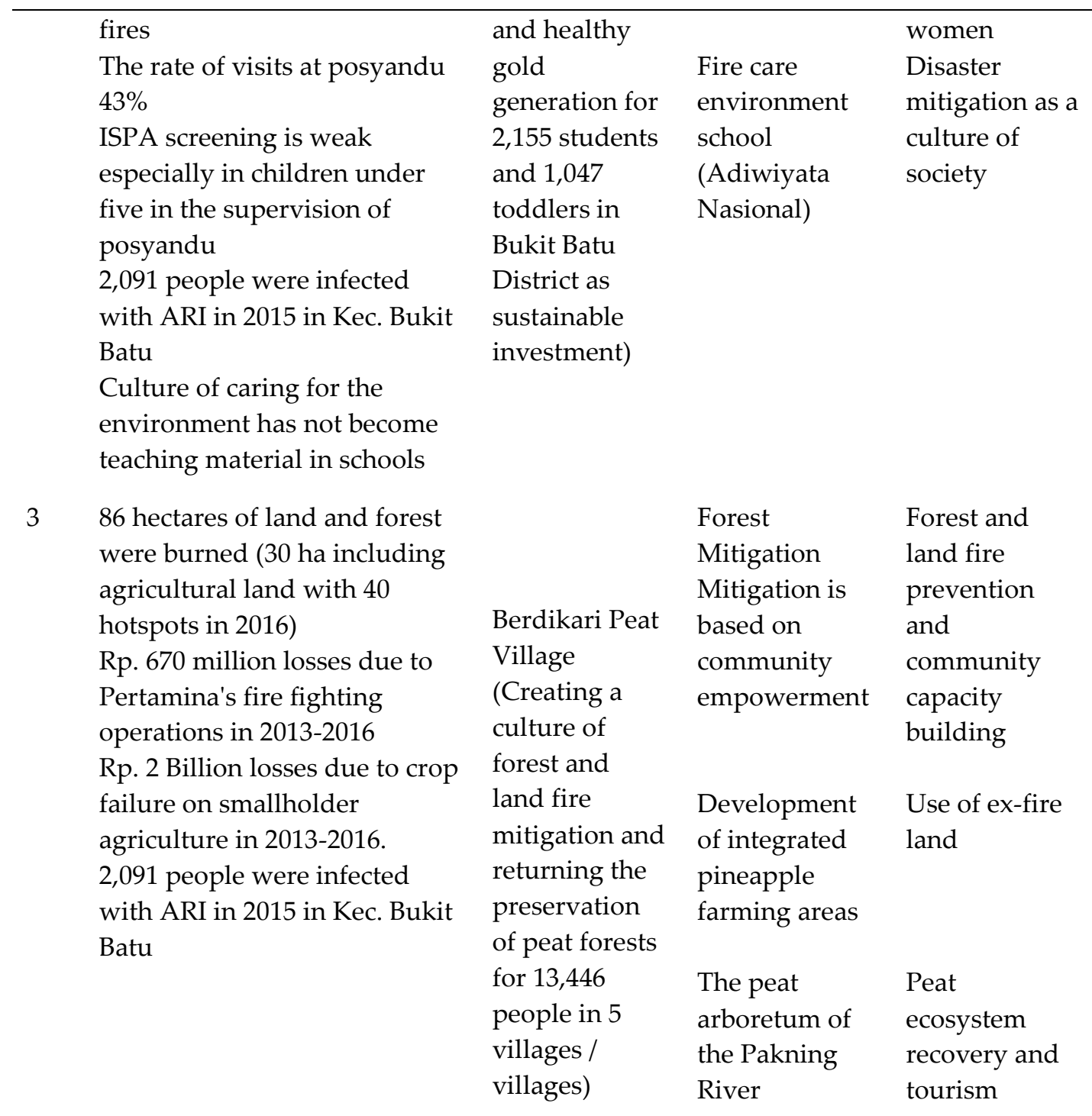

Source: Processed Data, 2019

The implementation of CSR programs carried out by companies is more directed towards empowerment which includes aspects of the economy, education, health, environment and infrastructure facilities and infrastructure that is sustainable in order to stand up the community and be able to answer the needs of vulnerable groups in the area of PT. Pertamina RU II Production Pakning River.

The vision of PT. Pertamina RU II Pakning River Production is to become a national oil and gas company that is a pioneer in the implementation of sustainable Corporate Social Responsibility (CSR) by paying attention to aspects of the people (people), environment (planet), and economy (profit) in order to create a prosperous community 
self-sufficiency at the level regional in 2030. This vision is in accordance with John Elkington's concept of people, planet, and profit (3P) in his book entitled Cannibals With Forks: The Triple Bottom Line in 21 "Century Business (1998), in this book Elkington develops three important components of sustainable development, namely economic growth, environmental protection, and social equity, initiated by The World Commission on Environment and Development (WCED) in Burtland Report (1987), Elkington packs CSR into three focuses: 3 P, which stands for profit, planet, and people. Good companies don't just hunt for environmental sustainability and the social benefits they add or destroy (Elkington, 1998).

\section{Methods}

In this study, researchers used a qualitative method, namely research beyond various stages of critical-scientific thinking, in which a researcher begins to think inductively, which captures various facts or social phenomena, through observation in the field, then analyzes them and then attempts to do theorization based on what was observed (Bungin, 2015). The research location is focused on PT. Pertamina RU II Pakning River Production namely Pangkalan Jambi Village, Tanjung Leban Village, Origin Pakning Village, Sejangat Village and Sungai Pakning Village Bukit Batu District Bengkalis Regency Riau Province.

\section{Results and Discussion}

PT. CSR Program Pertamina RU II Sungai Pakning Production has a superior program since 2016, previously CSR PT. Pertamina RU II Production River Pakning is more charity or philanthropy is just philanthropic activity even though it helps the community, but does not make the community independent. One indication of the success of the CSR program is that there is more independence in the community than before the CSR program. While the categories of infrastructure development, capacity building and community empowerment, although there are, are still very small in number, but since 2017 CSR funds have begun to pay attention to community empowerment programs and have begun to reduce charity programs. This can be seen in the table below: 
Table 2.

Planning and Realization of CSR Funds of

PT. Pertamina RU II 2015 Pakning River Production

\begin{tabular}{|c|c|c|c|c|c|}
\hline \multirow[b]{2}{*}{ Year2015 } & \multicolumn{5}{|c|}{ Kategori } \\
\hline & Charity & $\begin{array}{c}\text { Infrastructu } \\
\text { re }\end{array}$ & $\begin{array}{l}\text { Capacity } \\
\text { Building }\end{array}$ & $\begin{array}{c}\text { Community } \\
\text { Empowerm } \\
\text { ent }\end{array}$ & Total \\
\hline Plan & 275.000 .000 & 115.000 .000 & 35.000 .000 & 150.000 .000 & $\begin{array}{l}575.000 .00 \\
0\end{array}$ \\
\hline Percentage & $48 \%$ & $20 \%$ & $6 \%$ & $26 \%$ & $100 \%$ \\
\hline Realization & 255.282 .500 & 112.595 .000 & 31.500 .000 & 123.950 .000 & $\begin{array}{l}523.327 .50 \\
0\end{array}$ \\
\hline Success (\%) & $93 \%$ & $98 \%$ & $90 \%$ & $83 \%$ & $91 \%$ \\
\hline Benefit recipients & 810 & 292 & 149 & 25 & 1.276 \\
\hline
\end{tabular}

Source: PT. Pertamina RU II Pakning River Production, 2019

The table above shows that in 2015 PT. Pertamina RU II Production Pakning River totaling Rp. 575,000,000 with the realization of Rp. 523,327,500, - or about $91 \%$ with a total of 1,276 beneficiaries. Most CSR fund planning in the charity category is $48 \%$, the second category is community empowerment $26 \%$, the third infrastructure is $20 \%$ then the fourth is $6 \%$ capacity building. As for the highest CSR funds realization in the infrastructure category $98 \%$, second charity $93 \%$, third capacity building $90 \%$ and fourth community empowerment $83 \%$. The highest charity category beneficiaries were 810 beneficiaries, the second infrastructure category was 292 beneficiaries, the third was capacity building 149 beneficiaries and the fourth was community empowerment 25 beneficiaries. 
Tabel 3.

Perencanaan dan Realisasi Dana CSR PT. Pertamina RU II

Production Sungai Pakning Tahun 2016

\begin{tabular}{lccccc}
\hline \multicolumn{1}{c}{ Year 2016 } & Charity & Infrastructure & $\begin{array}{c}\text { Kategori } \\
\text { Capacity } \\
\text { Building }\end{array}$ & $\begin{array}{c}\text { Community } \\
\text { Empowerm } \\
\text { ent }\end{array}$ & Total \\
\hline Plan & 270.000 .000 & 15.000 .000 & 46.000 .000 & 180.000 .000 & 511.000 .000 \\
Percentage & $53 \%$ & $3 \%$ & $9 \%$ & $35 \%$ & $100 \%$ \\
Realization & 268.005 .000 & 15.000 .000 & 46.000 .000 & 177.233 .622 & 506.238 .622 \\
Success (\%) & $99 \%$ & $100 \%$ & $100 \%$ & $98 \%$ & $99 \%$ \\
Benefit recipients & 565 & 362 & 110 & 4.003 & 5.040 \\
\hline
\end{tabular}

Source: PT. Pertamina RU II Pakning River Production, 2019

The table above shows that in 2016 the CSR fund planning of PT. Pertamina RU II Production Pakning River has decreased from 2015 in the amount of Rp. 511,000,000, with an increase of Rp. 506,238,622 or around 99\% with the number of beneficiaries experiencing an increase of 5,040. CSR fund planning in the charity category has increased by $53 \%$, both categories of community empowerment have increased by $35 \%$, third capacity building has decreased $9 \%$ then to four infrastructure 3\%. Whereas the highest realization of CSR funds in the category of infrastructure and capacity building is $100 \%$, then charity $99 \%$, and community empowerment $98 \%$. For the beneficiaries the community empowerment category had the highest increase of 4,003 users, the two categories are charity 565 users, third infrastructure 362 users and fourth capacity building 110 users.

Table 4.

Planning and Realization of CSR Funds of PT. Pertamina RU II Production Pakning River in 2017

\begin{tabular}{lccccc}
\hline \multicolumn{1}{c}{ Year 2017 } & Charity & $\begin{array}{c}\text { Infrastructu } \\
\text { re }\end{array}$ & $\begin{array}{c}\text { Kapacity } \\
\text { Building }\end{array}$ & $\begin{array}{c}\text { Community } \\
\text { Empowerm } \\
\text { ent }\end{array}$ & Total \\
\hline Plan & 250.000 .000 & 75.000 .000 & 300.000 .000 & 1.200 .000 .000 & 1.825 .000 .000 \\
Percentage & $14 \%$ & $4 \%$ & $16 \%$ & $66 \%$ & $100 \%$ \\
Realization & 182.592 .000 & 48.550 .000 & 393.195 .000 & 1.195 .794 .756 & 1.820 .131 .756 \\
Success (\%) & $73 \%$ & $65 \%$ & $131 \%$ & $98 \%$ & $99 \%$ \\
Benefit recipients & 133 & 35 & 4.034 & 13.618 & 17.820 \\
\hline
\end{tabular}

Source: PT. Pertamina RU II Pakning River Production, 2019

The table above shows that in 2017 PT. Pertamina RU II Pakning River Production experienced a significant increase from 2015 and 2016 in the amount of Rp. 1,825,000,000, - 
with the realization of Rp. 1,820,131,756, or around 99\% with the number of beneficiaries experiencing an increase of 17,820 . CSR fund planning has started to focus on the community empowerment category because the benefits have begun to be felt by the community and PT. Pertamina, this is evidenced by an increase in CSR funds by $66 \%$, both categories of capacity building by $16 \%$, third charity has decreased dramatically by $14 \%$ then to four infrastructure $4 \%$. Whereas the highest and exceeding planning realization of CSR funds was in the capacity building category, namely $131 \%$, then community empowerment $98 \%$, charity category $73 \%$ and the lowest in the infrastructure category $65 \%$. For the beneficiaries the highest category of community empowerment increased by 13,618 beneficiaries, two categories of capacity building 4,034 beneficiaries, three charity 133 beneficiaries and four infrastructure 35 beneficiaries.

Table 5.

Planning and Realization of CSR Funds of PT. Pertamina RU II Production Pakning River in 2018

\begin{tabular}{cccccc}
\hline Year 2018 & Charity & $\begin{array}{c}\text { Infrastructur } \\
\mathbf{e}\end{array}$ & $\begin{array}{c}\text { Kategori } \\
\text { Capacity } \\
\text { Building }\end{array}$ & $\begin{array}{c}\text { Community } \\
\text { Empowerm } \\
\text { ent }\end{array}$ & Total \\
\hline Plan & 150.000 .000 & 100.000 .000 & 350.000 .000 & 1.600 .000 .000 & 2.200 .000 .000 \\
Percentage & $7 \%$ & $5 \%$ & $16 \%$ & $73 \%$ & $100 \%$ \\
Realization & 139.987 .000 & 98.550 .000 & 352.600 .000 & 1.543 .200 .000 & 2.134 .337 .000 \\
Success (\%) & $93 \%$ & $99 \%$ & $101 \%$ & $96 \%$ & $97 \%$ \\
Benefit recipients & 150 & 1.369 & 3.994 & 13.658 & 19.171 \\
\hline
\end{tabular}

Source: PT. Pertamina RU II Pakning River Production, 2019

The table above shows that in 2018 the CSR fund planning of PT. Pertamina RU II Production River Pakning has increased from 2017 which amounted to Rp. 2,200,000,000 with realization of Rp. $2,134,337,000$ or about $97 \%$ with the number of beneficiaries experiencing an increase of 19,171 . CSR fund planning in the community empowerment category has increased by $73 \%$, the two categories of capacity building by $16 \%$, the third charity has decreased by $7 \%$ then to four infrastructure $5 \%$. Whereas the highest realization of CSR funds and exceeding planning is in the capacity building category, which is $101 \%$, then infrastructure $99 \%$, the community empowerment category $96 \%$ and the lowest is the charity category $93 \%$. For the highest number of beneficiaries, there were 13,658 
beneficiaries, the second was capacity building 3,994 beneficiaries, the third infrastructure was 1,369 beneficiaries and the fourth charity was 150 beneficiaries.

From the above table, it is known that there was an increase in the percentage of the budget for the community empowerment category from 2015 (26\%), 2016 (35\%), 2017 (66\%) and 2018 (73\%) because they were considered to make the community more empowered, sustainable and towards independence. Whereas the charity category has decreased from 2016 (53\%), 2017 (14\%) and 2018 (7\%) because they are considered to make the community helpless, not independent, and only short-term or unsustainable. The activities carried out by PT. Pertamina RU II Production Pakning River are as follows:

1. Revitalization and Conservation of Mangrove Areas. Revitalization and conservation of mangrove areas aims to increase public awareness of the environment, especially mangrove areas and the formation of mangrove cultivation groups in the Bukit Batu District. The revitalization and conservation program of mangrove areas is carried out to solve problems in the marine coastal environment such as abrasion, the number of mangroves that die, making embankments and for more sustainable activities is an ecotourism area called the Permata Hijau Mangrove Education Center in Pangkalan Jambi and Mangrove Center in Tanjung Leban Village. This area was built to be a place of recreation as well as educating the public about the importance of preserving mangrove plants as an effort to prevent abrasion. The public can visit the mangrove area to see hundreds of mangrove seeds and taste culinary processed by fishermen groups such as mangrove chips and mangrove syrup. In addition, in the process of planting mangroves the community is taught to use hybrid engineering techniques that have been carried out by experts from several universities also involving community participation, especially fishermen groups in the village.

2. Development of Integrated Pineapple Agricultural Areas. One of the reasons for the establishment of an integrated pineapple farming program is as a form of management of burnt and unburnt peatlands into productive land and adjustments to the types of plants that can be cultivated on peatlands, in addition to sago, and pineapples are one type of plant that has economic value high. Starting from 2015, as many as 5000 pineapple seedlings were planted on an area of 0.5 hectares with a 
harvest period of about 8 months. In 2017, pineapple plantations will grow to 4.5 hectares with a total of 45,000 pineapple seedlings. Pineapple yields have also increased with a harvest period of 6 months. The integrated pineapple farming program in this case is intended as a pineapple cultivation program, which starts from planting, developing products from pineapple to pineapple waste treatment so that zero waste is not wasted. Kampung Jawa is a location for pineapple farming programs as well as being a pilot area. The formation of the Makmur Farmer group in Java Village was carried out to empower the community. In this case Pertamina's CSR helps diversify pineapple processed products by using appropriate technology. Through training and processing skills for processed pineapple products such as chips, sweets, dodol, diamonds and syrup. This effort succeeded in opening up employment opportunities for men and women in the Sungai Pakning region and increasing community income. The reason for choosing Java as a pilot location is because peatlands in Java are the only peatland free from severe fires that occurred a few years ago.

3. 3. Mitigation of Forest and Land Fire Based on Community Empowerment. Fire Concerned Community Target Group. The fire care community is a group formed by the village community to do voluntary work specifically to deal with forest and land fires. The form of community empowerment specifically given to people who care about fire that is carried out is the entrepreneurship program of people who care about fire as a first step to improve welfare and become new employment opportunities for the community, especially people who care about fire. As an example in terms of preventing forest and land fires, Pertamina's CSR collaborates with the Fire Concern Community (MPA) in 5 CSR-assisted villages Pertamina to mitigate disasters using Geographic Information Systems. Through disaster mitigation done, people concerned about fire can find out the points of disasterprone areas so that it is necessary to optimize the construction of canals and reservoirs. PT. Pertamina RU II Sungai Pakning Production also provides Fire Man 1 Certification (International Level Professional Certification as Professional Certification). The limited fire fighting facilities and infrastructure, the low awareness of the community to protect the environment and the low skills of the 
community are a strong basis that Pertamina's CSR is committed to participate in protecting the environment. CSR Commitment of PT. Pertamina RU II production of Sungai Pakning in an effort to prevent forest and land fires in the Bukit Batu Subdistrict area, among others, is by providing assistance in normalizing canals, reservoirs, providing facilities and infrastructure for fire-conscious communities and more pioneering is Fire Man certification. The Fireman certification program is a program intended for high school graduates to obtain international-level professional certification. Communities participating in this program will be given special training. The output of this program is the availability of certified, skilled and trusted firefighters who are expected to be able to increase the capacity and skills of the community and can be used to help resolve forest and land fire problems.

4. UMKM Development Based on Women's Empowerment and Trash 3R. Pertamina RU II Pakning River Production has fostered local MSMEs through CSR programs and put forward the concept of zero waste so as to encourage the application of low-carbon economic development that is environmentally friendly and has achieved UNS SME achievements, AWARDS category of Zero Waste MSME developers in 2017 and 2018 In Bukit Batu District, through PT Pertamina RU II Sei Pakning already has a SUCI Trash Bank (River Pakning, Excellent, Beautiful and Beautiful). Through this garbage bank, the community is taught how to process waste into compost and animal feed. waste bank is a solution in reducing waste transported to landfills (TPA) from community homes. The construction of a garbage bank in Sejangat Village, Bukit Batu District should be the initial momentum to develop awareness of the local community and its surroundings to create a clean and healthy lifestyle. the existence of this garbage bank is part of a strategy to build public awareness so that it can be friends with waste. In addition to getting direct economic benefits from the waste itself. Jr. The CSR Officer of Pertamina RU II Production Sungai Pakning hopes that with the existence of this garbage bank, the community's economy will be able to improve even more. Because household plastic waste is processed into tablecloths, tissue holders, sandals, bags and other knick-knacks. 
5. Development of the Peat Arboretum. The development of peat arboretum is a commitment of Pertamina RU II Production River Pakning to preserve the environment and empower people on peatlands with efforts to restore and tour peat ecosystems as a conservation area and peatland education will be developed for educational and tourism facilities especially for young people to introduce the function of peatlands as the main buffer of ecosystems in Riau Province. For this effort PT.Pertamina RU II Production Sungai Pakning received the highest award Dharma Krida Baraya Adikarya Anugraha in the 7th UNS Summit, 2018 Expo \& Awards category of sustainable environmental management especially on peatlands in Riau that are vulnerable to burning, through the CSR program titled ' Berdikari Peat Village '.

Adiwiyata School Development. The Adiwiyata school program is one of the programs of the Ministry of the Environment in an effort to encourage the creation of knowledge and awareness that starts from schools in environmental preservation efforts. In this program it is hoped that every school member can get involved in school activities towards a healthy environment and avoid negative environmental impacts. The objective of the Adiwiyata Program is to create good conditions for schools to become places for learning and awareness of school residents (teachers, students and other workers), so that in the future these school residents can take responsibility in efforts to save the environment and sustainable development. PT. Pertamina RU II Production of Sungai Pakning with the government in creating Adiwiyata schools was carried out in the form of providing support or support and assistance. SDN 003 Desa Sejangat, Bukit Batu Subdistrict is an Adiwiyata School under the guidance of Pertamina's CSR as an environmentally friendly school. SDN 003 Bukit Batu Subdistrict became SD Pembina from 9 elementary schools that were designated as Adiwiyata schools, and an environment-based curriculum was applied. As a form of Pertamina's collaboration with the government, the Adiwiyata school participated in the mangrove planting process and learned how to manage mangrove yields. In this case SDN 003 Bukit Batu District already has processed mangrove products, namely dyes from mangroves, Green House development, formed education groups and the last is batik products created from 
mangroves. There is an adiwiyata school development program by implementing a mangrove-based environmental curriculum and a teaching pertamina program carried out by Pertamina employees and related parties such as the Agriculture Office and the Ministry of the Environment. By increasing the hours for students to understand more about mangrove plants through integrated activities such as a competition to make batik designs from mangroves and the creation of mangrove green houses.

6. Development of Posyandu Sehati. The development of the Posyandu Sehati is a special program for the health sector, one of which is the assistance of Supplementary Feeding (PMT) for infants and toddlers, ISPA socialization, spa and also massage for babies. In this program PT. Pertamina RU II Production Pakning River contributes to efforts to improve child nutrition and reduce maternal, infant and under-five mortality rates towards a better life. In its implementation, Pertamina cooperates with the Indonesian Family Planning Association (PKBI). Pertamina manages this program through the CSR function which functions as the initiator and supervisor of the program as well as the provider of funds and budget funds. Meanwhile, PKBI as a working partner acts as a program facilitator and facilitator.

\section{Conclusion}

PT. CSR Program Pertamina RU II Production Pakning River which is carried out purely to empower the community so that the company does not benefit in nominal figures, the benefits derived only from positive community responses so as to form a good corporate image and reputation in the eyes of the community. In implementing all the programs contained in the Work Plan and Strategic Plan, of course the CSR PT. Pertamina RU II Production of Sungai Pakning cannot work alone but requires collaboration with several stakeholders or stakeholders. In this case the stakeholders involved are the Bengkalis District Government, the Village Government, the community, the University of Riau academics, tourists, environmentally friendly communities and social groups in order to assist in the promotion of both electronic media, print media and social media. With the cooperation carried out with stakeholders can form a good relationship between the 
company and stakeholders. PT. Pertamina RU II Production of Sungai Pakning in carrying out CSR programs uses a partnership pattern with stakeholders such as government, community and other institutions. The partnership pattern can be described as below:

Figure 1.

CSR Program Partnership Pattern PT. Pertamina RU II Production Sungai Pakning

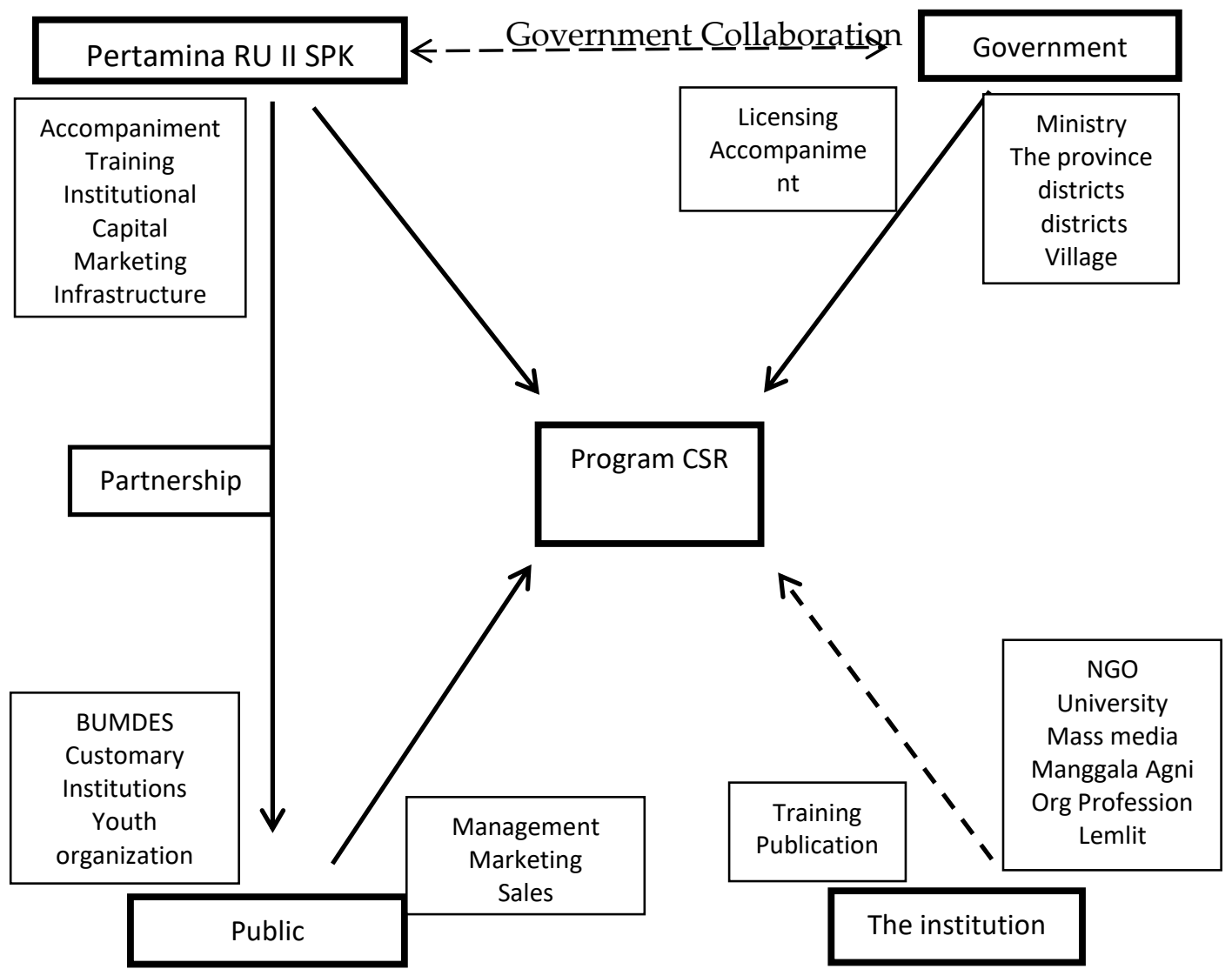

\section{References}

Alfitri. 2011. Community Development. Yogyakarta: Pustaka Pelajar

Bungin. M. B. 2015. Penelitian Kualitatif. Jakarta: Prenada Media Grup.

Carroll, A. B. 2009. A History of Corporate Social Responsibility: Concepts and Practices. In The Oxford Handbook of Corporate Social Responsibility. https://doi.org/10.1093/oxfordhb/9780199211593.003.0002

Elkington, J. (1998). Partnerships from cannibals with forks: The triple bottom line of 21stcentury business. Environmental Quality Management. https://doi.org/10.1002/tqem.3310080106 
Geva, A. (2008). Three Models of Corporate Social Responsibility: Interrelationships between Theory, Research, and Practice. Business and Society Review. https://doi.org/10.1111/j.1467-8594.2008.00311.x

Holmqvist, M. 2009. Corporate Social Responsibility as Corporate Social Control: The Cose of Work-Site Health Promotion, Scandinavian Journal of Management 25, p. 68-72

Hopkins, M. 2004. Corporate Social Responsibility: An Issue Paper. Working Paper No. 27, Policy Integration Department, World Commission On The Social

Lamberti, L. and Lettieri, E. 2009. CSR Practices and Corporate Strategy: Evidence from a Longitudinal Case Study, Journal of Business Ethics (2009) 87: p. 153-168.

Lantos, G.P. 2001. The Boundaries of Strategic Corporate Social Responsibility, Journal of Consumer Marketing, Vol. 18, No. 7. P. 595630.

Mardikanto. T. 2014. Corporate Social Responsibility. Bandung: Alfabeta

Mardikanto.T dan Soebiato. P. 2015. Pemberdayaan Masyarakat dalam Perspektif Kebijakan Publik. Bandung: Alfabeta.

WCED (World Commi;sion on Environment and Development), 1987. Our common future: The Brundtland report. Oxford: Oxford University Press.

Welford, R. 2004. Corporate Social Responsibility in Europe, North America and Asia, Journal of Corporate Citizenship 17 (Spring 2005): 33-52. University of Hong Kong: Greenleaf Publishing.

Zuo, W. 2008. Strategizing Corporate Social Responsibility; Evidence from Guangdong Wen's Foodstuffs Group Co., International Journal of Business and Management, Vol. 3, No. 8. p. 31-38 